\title{
Calcineurin and glial signaling: neuroinflammation and beyond
}

\author{
Jennifer L Furman ${ }^{2}$ and Christopher M Norris ${ }^{1 *}$
}

\begin{abstract}
Similar to peripheral immune/inflammatory cells, neuroglial cells appear to rely on calcineurin (CN) signaling pathways to regulate cytokine production and cellular activation. Several studies suggest that harmful immune/ inflammatory responses may be the most impactful consequence of aberrant CN activity in glial cells. However, newly identified roles for $\mathrm{CN}$ in glutamate uptake, gap junction regulation, $\mathrm{Ca}^{2+}$ dyshomeostasis, and amyloid production suggest that CN's influence in glia may extend well beyond neuroinflammation. The following review will discuss the various actions of CN in glial cells, with particular emphasis on astrocytes, and consider the implications for neurologic dysfunction arising with aging, injury, and/or neurodegenerative disease.
\end{abstract}

Keywords: Alzheimer's disease, Amyloid, Astrocytes, $\mathrm{Ca}^{2+}$ regulation, Calcineurin, Gap junction, Glutamate, Neurodegeneration, Neuroinflammation

\section{Background}

Calcineurin $(\mathrm{CN})$ is a $\mathrm{Ca}^{2+} /$ calmodulin $\left(\mathrm{Ca}^{2+} / \mathrm{CaM}\right)$-dependent protein phosphatase expressed in most mammalian tissues, but found at especially high levels in brain. The $\mathrm{CN}$ holoenzyme is a heterodimeric protein containing a $60 \mathrm{kDa}$ catalytic subunit (CN A) and a $19 \mathrm{kDa}$ regulatory subunit (CN B). Multiple isoforms of both subunits have been identified and are expressed differentially throughout brain and most other tissues (for review see [1-3]). CN A contains the catalytic core as well as binding sites for the $\mathrm{CN}$ B subunit and $\mathrm{Ca}^{2+} / \mathrm{CaM}$. There is also a critical autoinhibitory domain located near the $\mathrm{C}$ terminus of $\mathrm{CN}$ A that suppresses catalytic activity when $\mathrm{Ca}^{2+}$ levels are low. The CN B subunit contains four $\mathrm{Ca}^{2+}$-binding EF-hand motifs and is generally physically bound to $\mathrm{CN}$ A at resting $\mathrm{Ca}^{2+}$ levels. Allosteric interactions between $\mathrm{CN} \mathrm{B}$, $\mathrm{Ca}^{2+} / \mathrm{CaM}$, and the autoinhibitory domain allow $\mathrm{CN}$ to respond to rapid $\mathrm{Ca}^{2+}$ fluctuations with relatively high fidelity $[4,5]$. Within the cell, $\mathrm{CN}$ can be found throughout the cytosol and the nucleus, and is also commonly associated with membrane receptors, ion channels, and pumps via physical interactions with a variety of anchoring proteins $[1,3]$.

\footnotetext{
* Correspondence: cnorr2@uky.edu

'Pharmacology and Nutritional Sciences and the Sanders-Brown Center on Aging, University of Kentucky College of Medicine, 800 South Limestone St., Lexington, KY 40536, USA

Full list of author information is available at the end of the article
}

Immunohistochemical and in situ hybridization studies on healthy adult rat brain performed in the mid-1980s to early 1990s reported high levels of $\mathrm{CN}$ in neurons of the striatum, hippocampus, amygdala, and neocortex [6-9], with little to no expression observed in glial cells $[6,7]$. Many functional studies performed around this time found that $\mathrm{CN}$ plays an integral role in coupling glutamate receptor activation to the regulation of cytoskeletal proteins and dendritic spine morphology $[10,11]$. Since these initial studies, $\mathrm{CN}$ has been shown to interact with numerous neuronal substrates and to modulate diverse cellular functions including receptor and ion channel trafficking, ion channel function, apoptosis, and gene regulation, to name a few [2]. In the last 10 years, there have been a steadily increasing number of studies identifying neuronal $\mathrm{CN}$ as a primary suspect in synapse loss, dendritic atrophy, synaptic dysfunction, and neuronal vulnerability $[12,13]$. Nevertheless, despite the apparently selective association of $\mathrm{CN}$ with neurons and neuronal signaling cascades, a handful of reports in the mid- to late 1990s found that $\mathrm{CN}$ can also appear in primary glial cells and glial cells of intact brain tissue, notably following inflammatory insult [14-17]. The clear connection between glial cells and neuro-immune/inflammatory signaling, in addition to the well-defined role of $\mathrm{CN}$ in cytokine production in peripheral immune cells, suggested a strong linkage between glial $\mathrm{CN}$ and the neuroinflammation inherent to most 
acute and chronic neurodegenerative diseases. Recent and ongoing work from our group and others has not only largely confirmed $\mathrm{CN}$ as a major modulator of immune/ inflammatory processes in glial cells, but has also identified other possible functions for glial $\mathrm{CN}$ signaling that may have a major impact on neurologic function. This article reviews the functional implications associated with glial $\mathrm{CN}$ expression.

\section{Review}

\section{$\mathrm{CN}$ and glial cells}

Though primarily localized to neurons in healthy nervous tissue, $\mathrm{CN}$ may also be strongly expressed in glia during aging, injury, and/or disease. Greater numbers of $\mathrm{CN}$ positive astrocytes have been reported in the hippocampus of aged, $\beta$-amyloid $(\mathrm{A} \beta)$-bearing transgenic amyloid precursor protein/presenilin 1 (APP/PS1) mice, particularly in the immediate vicinity of extracellular $\mathrm{A} \beta$ deposits [18]. A similar relationship between $\mathrm{CN}$-positive astrocytes and $A \beta$ pathology was shown in postmortem brain tissue obtained from human subjects diagnosed with Alzheimer's disease (AD) [19-21]. Though closely associated with A $\beta$ deposits, the expression of $\mathrm{CN}$ in astrocytes does not necessarily depend on the presence of $\mathrm{A} \beta$. Indeed, aged wild-type mice showed a far greater number of $\mathrm{CN}$ positive astrocytes compared to younger wild-type mice, while expression of $\mathrm{CN}$ in astrocytes of APP/PS1 mice could be detected as early as three months of age, long before the appearance of extensive plaque pathology in this model [18]. The presence of numerous $\mathrm{CN}$-positive astrocytes in human hippocampus at very early stages of cognitive decline [19] suggests that the upregulation of $\mathrm{CN}$ in astrocytes is an antecedent to dementia found at later disease stages. In addition to aging and $\mathrm{AD}, \mathrm{CN}$ expression in astrocytes has also been reported for animal models of acute injury. In an early study by Hashimoto et al. [16], an increase in astrocytic $\mathrm{CN}$ labeling was observed in gerbil hippocampus following bilateral carotid artery occlusion, even though whole tissue levels of $\mathrm{CN}$ were reduced (as measured by Western blot). Shifting expression patterns for $\mathrm{CN}$ during aging, injury, and disease are notable because of the timing, i.e., CN can appear in astrocytes before widespread pathology is observed, and also because of the selectivity, i.e., increased $\mathrm{CN}$ expression only appears to occur in a subset of astrocytes. These findings suggest that changes in $\mathrm{CN}$ serve unique and perhaps critical roles in the initiation and progression of neurodegeneration and cognitive decline.

\section{Phenotype switching in astrocytes and neuroinflammation}

Astrocytes are an abundant and diverse subtype of glia. As a critical component of the neurovascular unit, astrocytes ensheath most microvessels via specialized end- foot processes, which help to maintain the integrity of the blood-brain barrier and promote osmotic balance (for review see [22]). Many astrocyte processes are also in close juxtaposition to synapses where they coordinate nutrient exchange to neurons and detoxify the local environment via the uptake of $\mathrm{K}^{+}$, glutamate, and other neurotransmitters [23,24]. Redistribution of imported factors and excitotoxins across numerous neighboring astrocytes is accomplished by an extensive gap junction network, which helps minimize local concentration gradients [25]. By ensheathing synapses, astrocytes play an essential role in establishing and maintaining the structural integrity of nerve terminals and dendritic spines, which, in turn, ensures the fidelity of interneuronal communication. In healthy central nervous system (CNS) tissue, astrocytes effectively carry out all of these functions, plus others. However, with CNS injury, astrocytes often look and appear to behave in very different ways. Hypertrophy of astrocyte somata and processes, with a corresponding increase in the expression of the intermediate filament protein, glial fibrillary acidic protein (GFAP), is a pervasive feature of nearly every form of acute CNS injury as well as most chronic neurodegenerative disorders $[22,26,27]$. These changes have been extensively documented and are commonly referred to as "astrocyte activation" or "astrocyte reactivity" [28].

Along with activated microglia, astrocyte activation is widely accepted as a hallmark of neuroinflammation, though the functional phenotype of activated astrocytes remains somewhat elusive. Protective roles for activated astrocytes, particularly after acute injury, have been demonstrated by many studies (for a review, see [29]). However, if not properly resolved, astrocyte activation can become a chronic condition with apparently detrimental effects on neuronal function and plasticity [28,30]. Activated astrocytes secrete numerous pro-inflammatory cytokines and other factors that can interfere with synaptic fidelity, impair neuronal viability, and/or maintain the activation state of astrocytes and microglia [31-33]. Activated astrocytes also appear to be compromised in their ability to take up excitotoxins (e.g., $\mathrm{K}^{+}$and glutamate) from the extracellular milieu, which could, in turn, lead to further synaptic dysfunction, neuronal damage, and neuroinflammation $[19,28,33,34]$. The appearance of activated astrocytes at very early stages of cognitive impairment in humans [35-37] suggests that astrocyte activation may help initiate and/or drive other pathophysiological changes leading to dementia.

We have hypothesized that $\mathrm{CN}$ is a critical mechanism for triggering phenotype switching (i.e., activated vs. nonactivated) and neuroinflammatory signaling inherent to astrocytes during neural damage and dysfunction [13,18,33]. In many peripheral tissues, $\mathrm{CN}$ is a pivotal regulator of transcriptional programs involved in cellular remodeling 
$[38,39]$. Perhaps the best documented example is the role that $\mathrm{CN}$ plays in the adaptive immune response through the activation of NFATs (Nuclear Factor of Activated T cells) and $\mathrm{NF}_{\kappa} \mathrm{B}$ (Nuclear Factor $\kappa \mathrm{B}$ ) transcription factors. In the resting state, NFATs and NFkB are both sequestered in the cytosol, albeit by different mechanisms. The nuclear translocation signal of NFATs is masked by hyperphosphorylation. When activated, $\mathrm{CN}$ directly binds to and dephosphorylates NFATs, exposing the nuclear translocation signal and promoting the accumulation of NFATs in the nucleus [40]. A similar nuclear localization signal is present in $\mathrm{NF}_{k} \mathrm{~B}$, but is masked not by hyperphosphorylation, but by the binding of subunits called inhibitory $\mathrm{kBs}$ (IkBs) [41]. CN helps promote the activation of IkB kinases [42], which phosphorylate and tag $I \kappa B$ for proteasomal degradation, thereby allowing nuclear translocation of NFkB. Once in the nucleus, NFATs and NFkB interact with distinct DNA binding elements to drive the expression of multiple cytokine species that promote (or in some cases suppress) the clonal expansion of T cells.

In astrocytes, $\mathrm{CN}$ appears to represent a fundamental link between morphological changes and immune/inflammatory signaling. Forced expression of activated $\mathrm{CN}$ in primary mixed neuron/glia cultures was sufficient to cause an increase in the width of astrocyte somata and processes [18], while inhibition of astrocytic CN/NFAT activity in intact amyloid-bearing mice caused a reduction in the surface area of individual hippocampal astrocytes without affecting overall cell number [43]. Multiple extracellular factors that trigger astrocyte hypertrophy and/or neuroinflammation, including many "pro-inflammatory" cytokines (e.g., interleukin $1 \beta$ (IL-1 $\beta$ ), tumor necrosis factor $\alpha$ (TNF $\alpha$ ), and interferon $\gamma$ ), glutamate, ATP, thrombin, $\mathrm{S} 100$, and $\mathrm{A} \beta$ also robustly activate $\mathrm{CN}$ in primary astrocyte cultures [19,21,33,44-48]. Once activated, $\mathrm{CN}$ helps drive the expression of numerous immune/inflammatory factors in astrocytes [18,33,44,45], many of which are found at elevated levels during injury, aging, and neurodegenerative disease [49-54]. Moreover, we have found that astrocytic CN/NFAT activity can propagate from one astrocyte population to another in an autostimulatory manner [33].

Through its actions on NFAT- and NFkB-dependent transcriptional regulation, $\mathrm{CN}$ appears ideally suited to drive the self-perpetuating "cytokine cycles" implicated in chronic neuroinflammation [54,55]. Indeed, similar immune/inflammatory functions of $\mathrm{CN}$ have been observed in microglia [56-59], confirming CN's role as a global mediator of neuroinflammation. Nonetheless, it is probably too simplistic to think of $\mathrm{CN}$ strictly as a "proinflammatory" mechanism. Extensive work on peripheral immune cells tells us that $\mathrm{CN}$ activation can participate in diametrical processes, e.g., cytokine production and clonal expansion under some conditions, and lymphocyte anergy and/or tolerance under different conditions [60]. Such opposing phenotypic characteristics may depend, in part, on the association of $\mathrm{CN}$ with a variety of transcription factors. T cell activation, for instance, is largely driven by synergistic actions of NFATs and activator protein 1 (AP1) [40,61] (Figure 1A), while T cell tolerance and/or anergy has been shown to result from interactions between NFATs and forkhead box P3 (FOXP3) [61,62]. Based on these observations in T cells, it is not surprising that $\mathrm{CN}$ has been shown to have "anti-", as well as, "pro-" inflammatory effects in astrocytes. In a series of studies from Torres-Aleman's group, $\mathrm{CN}$ was implicated in both the initiation and resolution of neuroinflammatory signaling in acutely injured mice [45] or mice with progressing amyloid pathology [63]. In the latter study, performed on APP mice expressing a dox-inducible $\mathrm{CN}$ fragment in astrocytes, $\mathrm{CN}$ was shown to differentially affect neuroinflammation through its interactions with $\mathrm{NFKB}_{\mathrm{K}}$, peroxisome proliferator-activated receptor $\gamma$ (PPAR $\gamma$ ), and/or forkhead box O3 (FOXO3) transcription factors. These interactions were governed by the presence of specific extracellular factors. TNF $\alpha$ was shown to stimulate interactions between $\mathrm{CN}, \mathrm{FOXO}$, and $\mathrm{NF} \kappa \mathrm{B}$ leading to increased inflammatory signaling, while insulin-like growth factor (IGF-1) was shown to disrupt the pro-inflammatory interactions between $\mathrm{CN}, \mathrm{NFkB}$, and FOXO3 (Figure 1B) in favor of anti-inflammatory interactions between $\mathrm{CN}$, $\mathrm{NF}_{\kappa} \mathrm{B}$, and PPAR $\gamma$ (Figure $1 \mathrm{C}$ ).

Even the presence of different NFAT isoforms can dramatically alter the functional impact of elevated $\mathrm{CN}$ activity. A striking example of this is found in muscle tissue where NFAT4 is selectively activated by $\mathrm{Ca}^{2+}$ elevations in myoblasts, while NFATs 1 and 2 are selectively activated by the same kind of stimulation in myotubes [64]. In skeletal muscle fibers from adult rats, different NFAT isoforms showed varying sensitivities to different stimulation frequencies and regulated distinct genes associated with slow- and fast-twitch transcriptional programs [65]. The idea that individual NFAT isoforms play various roles in astrocyte function has been proposed by our lab and others $[13,19,66-68]$. We discovered that early stages of cognitive decline were associated with increased nuclear levels of NFAT1 in astrocytes, while NFAT3 was more strongly associated with astrocytes during late stages of AD [19]. Based on the clear association between the NFAT1 isoform and cytokine expression in lymphocytes, as well as the comparatively weak association of NFAT3 with lymphoid tissues [40], we have suggested that NFAT1 is more strongly linked to the neuroinflammatory phenotype of astrocytes [13]. In contrast, NFAT3 has been more closely linked to cell death and degeneration in multiple cell types (e.g., see [69-71]), suggesting that the demise of astrocytes in severe forms of injury/disease results from the selective activation of NFAT3. The other 


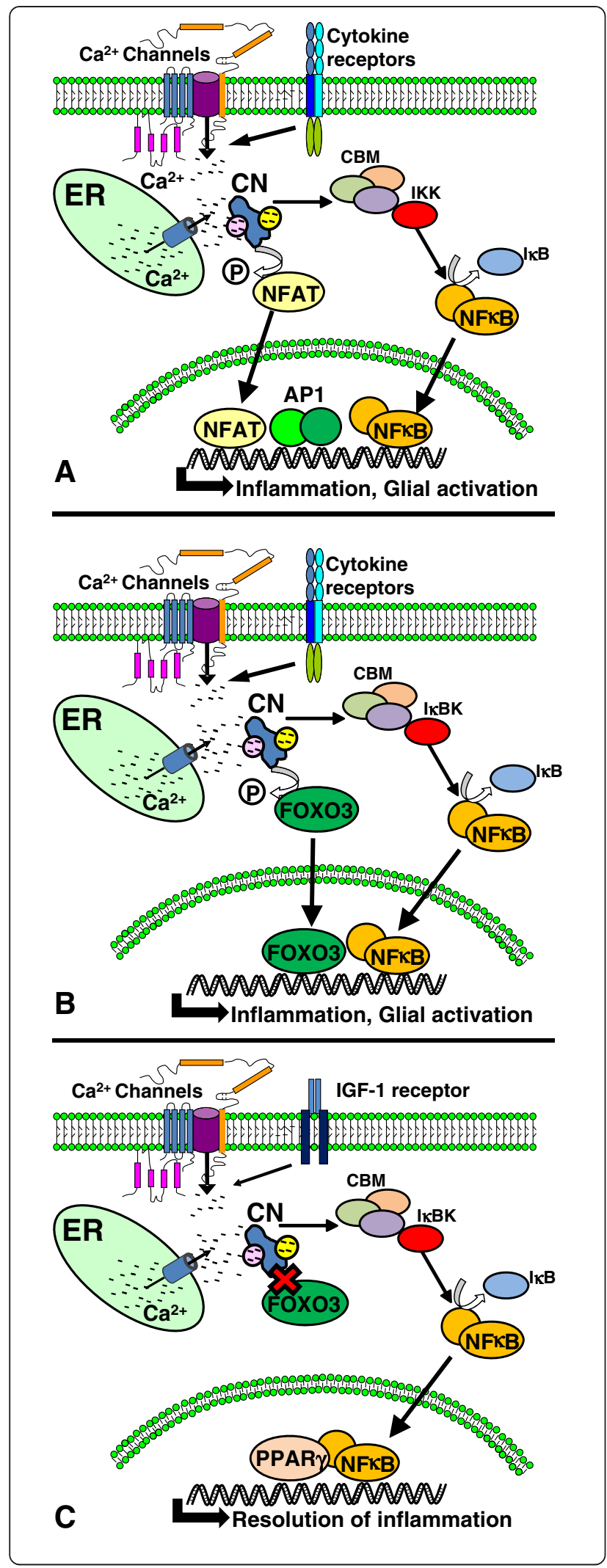

Figure $1 \mathrm{CN}$ pathways can drive or resolve neuroinflammatory signaling in glial cells. (A) Factors that activate glial cells, including multiple cytokine species and $\mathrm{A} \beta$ peptides, stimulate $\mathrm{Ca}^{2+}$ release from endoplasmic reticulum (ER) and/or $\mathrm{Ca}^{2+}$ influx across $\mathrm{Ca}^{2+}$ channels in the plasma membrane leading to $\mathrm{CN}$ activation. $\mathrm{CN}$ directly dephosphorylates and activates NFATs. CN also facilitates the recruitment of IKB kinases (IKK) to the CARMA1-BCl10-MALT1 (CBM) complex, which, in turn, causes the phosphorylation of $I_{K B}$ and the release (i.e., activation) of NFKB. NFATs and NFKB translocate to the nucleus, and with other transcription factors, such as AP1, drive the expression of numerous cytokines involved in the generation and maintenance of neuroinflammation. (B) CN can also dephosphorylate and activate $\mathrm{FOXO} 3$ transcription factors, which can also synergize with NFKB to drive immune/inflammatory signaling in glial cells. (C) Activation of IGF-1 receptors in glial cells also stimulates CN but suppresses its interaction with FOXO3. Simultaneous activation of PPARY and NFKB by IGF-1 regulates transcriptional programs that reduce or resolve neuroinflammation.

$\mathrm{CN}$-dependent NFAT isoforms (i.e., NFATs 2 and 4) have also been detected in astrocytes and microglia at the mRNA and protein levels [47,56,59,66-68,72-74]. Several recent studies have reported a striking increase in NFAT4 expression in a subgroup of astrocytes following acute CNS trauma $[67,68,73]$, though the subcellular localization of NFAT4 seemed to be limited to the cytosol, with very little expression found in astrocyte nuclei [67]. Other groups have shown that NFAT4 is indeed active in astrocytes and regulates the expression of transcripts involved in $A \beta$ production [66], as discussed in a later section of this review.

In summary, the available literature suggests that $\mathrm{CN}$ plays a major role in shaping the neuroinflammatory phenotype of astrocytes. The impact of $\mathrm{CN}$ on neuroinflammation appears to be complex and may depend upon the coactivation of other intracellular signaling pathways and/or the association of $\mathrm{CN}$ with multiple transcription factors, including different NFAT isoforms, NFKB, AP1, FOXO3, and others. These differential $\mathrm{CN}$ interactions likely do not simply promote a global phenotypic change but instead may selectively affect specific glial functions (Figure 1).

\section{$\mathrm{CN}$ and astrocyte-mediated glutamate regulation}

One of the most important functions of astrocytes is the removal of potentially toxic factors from the extracellular milieu, including $\mathrm{K}^{+}$, glutamate, GABA, and many others. Glutamate is cleared by astrocytes using a variety of excitatory amino acid transporters (EAATs), which energetically couple glutamate uptake to the import of $\mathrm{Na}^{+}$ions. The EAAT2 isoform (or Glt 1) is expressed predominantly in astrocytes and plays a lead role in glutamate clearance from many brain regions [75]. Loss of EAAT expression and/or function has been linked to a variety of neurologic diseases including $\mathrm{AD}$, amyotrophic lateral sclerosis, Parkinson's disease, and epilepsy, among others (for reviews, see $[24,75,76]$ ). Elevated amyloid 
levels in human AD brain tissue and in AD animal models is associated with a loss of EAAT expression and/or function [19,77-83]. This loss can occur very early in the progression of cognitive deficits [19], suggesting that changes in glutamate regulation may be key to the initiation/ propagation of neuronal degeneration and death. Common phenotypic characteristics of multiple disease models, including increased susceptibility to excitotoxicity, altered synaptic plasticity, and impaired cognition can be recapitulated in otherwise healthy animals by genetically or pharmacologically knocking down EAAT function [84-86]. These observations and many others make EAATs an intensely studied molecular target for preventing and/or limiting neurologic deficits associated with injury and disease.

Changes in EAATs appear to be strongly linked to the activated astrocyte phenotype. Immunohistochemical analyses of postmortem human brain sections revealed an inverse correlation between EAAT2 and GFAP expression levels [87]. Moreover, multiple extracellular factors that trigger profound astrocyte activation (including pro-inflammatory cytokines and $\mathrm{A} \beta$ ) can cause a reduction in EAAT expression and/or function in cell culture and animal models $[19,33,77,83,88-90]$. Numerous mechanisms have been proposed for regulation of EAATs at the transcriptional, translational, and post-translational levels. Many of these mechanisms show strong sensitivity to immune/inflammatory signaling factors implicated in astrocyte activation [91]. In regard to transcriptional regulation, binding sites for $\mathrm{NF}_{\kappa} \mathrm{B}$ and NFAT have been verified in the human EAAT2 promoter [92]. Interestingly, $\mathrm{NF} \mathrm{B}$ appears to play critical roles in both the up- and down-regulation of EAAT2 expression levels. Exposure to a variety of protective/reparative factors, including epidermal growth factor and TGF- $\beta$, causes an NFkB-mediated increase in EAAT2 expression, while pro-inflammatory factors like TNF $\alpha$ reduce EAAT2 levels in an NFKBdependent manner [92]. In our work on primary astrocytes $[19,33]$, reductions in EAAT2 levels following treatment with IL-1 $\beta$ or oligomeric $A \beta$, were strongly inhibited by pretreatment with VIVIT, an NFAT inhibitory peptide. In addition to preserving EAAT levels, VIVIT lowered extracellular glutamate, dampened neuronal hyperactivity, and reduced the appearance of excitotoxic neuronal death. Given the relatively close proximity between the $\mathrm{NF}_{\kappa} \mathrm{B}$ and NFAT binding sites within the EAAT2 promoter [92], we suggest that the downregulation of EAAT2 during astrocyte activation and/or neuroinflammation is largely attributable to the synergistic actions of $\mathrm{CN}, \mathrm{NF}_{\mathrm{K}} \mathrm{B}$, and NFAT (Figure 2). Additional work will be required to determine the viability of this combinatorial mechanism for EAAT2 regulation, and to identify possible conditions in which NFATs positively regulate EAAT2 expression to promote glutamate uptake.

\section{$\mathrm{CN}$, astrocytes, and gap junctions}

Astrocytes are extensively coupled to one another and, to a lesser degree, to other cell types via gap junctions (GJ). The GJ channel consists of a hexamer of specialized proteins called connexins $(\mathrm{Cx})$, which are localized to the cell membrane and directly apposed to a similar Cx hexamer localized to the plasma membrane of another cell [25]. The channel formed from apposing connexin hexamers (i.e., $\mathrm{Cx}$ hemichannels) can accommodate the passage of molecules up to $\sim 1.2 \mathrm{kDa}$ and provides a direct cytoplasm-to-cytoplasm pathway for adjacent astrocytes. GJs permit the exchange of numerous small molecules and signaling factors between cells including ions, nucleotides, and amino acids. Passage of critical second messengers across GJs, such as $\mathrm{Ca}^{2+}$ and inositol trisphosphate (IP3), also allow groups of astrocytes to respond in synchrony to highly localized extracellular signaling factors, which, in turn, can influence the plasticity of local synaptic ensembles and/or modulate the tone of the local vascular network [93]. In addition to forming GJs, some Cx hemichannels are unapposed (i.e., not coupled to $\mathrm{Cx}$ hemichannels on other cells) and provide a direct path between the astrocyte cytoplasm and the extracellular milieu. Unapposed Cx hemichannels are generally found in a closed channel state, but may become permeable during brain injury and disease [25].

The diffusion of $\mathrm{K}^{+}$and glutamate across GJ-coupled astrocyte networks during high levels of neuronal activity is one of the fundamental mechanisms for preserving high fidelity interneuronal communication and for preventing excitotoxicity [94]. Transgenic mice lacking Cx43 and/or Cx30 (i.e., the major connexin subtypes found in mature astrocytes) show heightened vulnerability to seizure activity and neuronal death, and may exhibit a variety of neurologic alterations (e.g., altered motor function and impaired cognition) depending on the brain region targeted [95-97]. On the other hand, increased GJ permeability may expose otherwise healthy astrocytes to toxic signals carried from sites of injury or pathology. In this way, GJs have been suggested as a mechanism for spreading pathophysiology [98].

Similar to EAATs, astrocytic GJs are highly sensitive to extracellular factors linked to neuroinflammation and exhibit altered expression and/or function in a variety of different neurologic disorders and diseases [94,99]. Multiple pro-inflammatory cytokines have been shown to either reduce $\mathrm{Cx} 43$ expression levels or reduce GJ coupling [100]. The $\mathrm{C}$ terminus tail region of $\mathrm{Cx} 43$, in particular, contains numerous phosphorylation sites that are regulated by inflammation-sensitive protein kinases [101]. Several research groups have also demonstrated stimulusevoked dephosphorylation of $\mathrm{Cx} 43$ in primary astrocytes, suggesting the dynamic involvement of protein phosphatases [102,103]. Specific dephosphorylation of ser368 in 
A

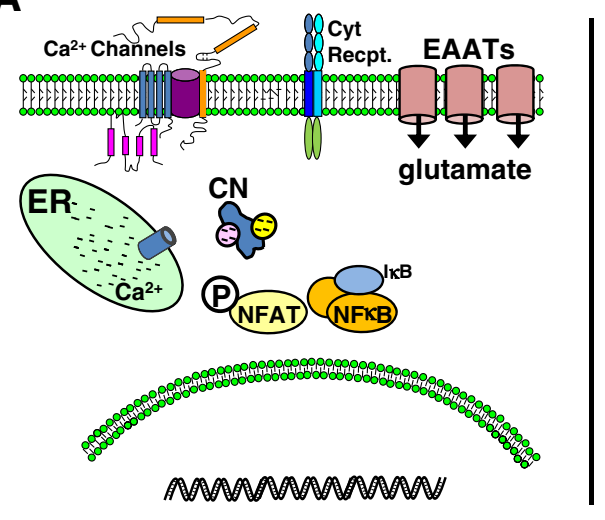

B

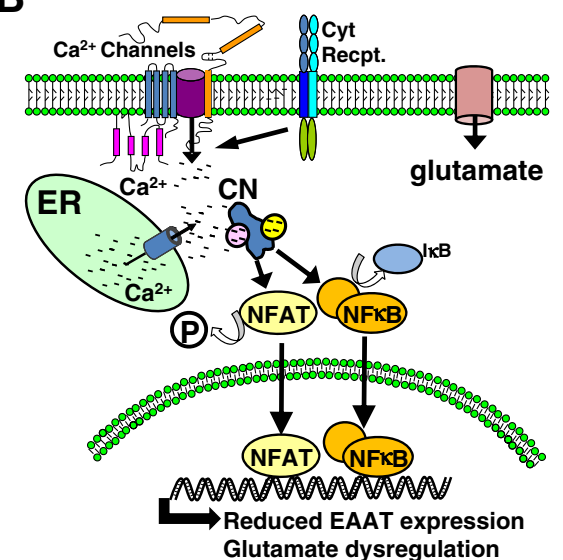

Figure $\mathbf{2}$ CN-mediated impairment of glutamate uptake in astrocytes. (A) In healthy nervous tissue, astrocytes remove excess glutamate from the extracellular milieu using EAATs. (B) Pro-inflammatory cytokines and A $\beta$ cause hyperactivation of $C N$ in astrocytes leading to the activation of NFAT and NFKB transcription factors. Together, and possibly individually, NFATs and NFKB suppress the transcription of EAATs. Loss of EAAT protein is associated with reduced glutamate uptake, higher extracellular glutamate levels, and increased excitotoxicity.

the Cx43 cytoplasmic tail can occur within minutes following a hypoxic insult or after treatment with endogenous factors linked to vascular damage and astrogliosis and is highly sensitive to CN activation [102,103]. Dephosphorylation of ser368 in primary astrocytes following hypoxia or treatment with extracellular factors, such as endothelin-1 and phingosine-1-phosphate, was mostly prevented by pretreatment with commercial $\mathrm{CN}$ inhibitors (i.e., cyclosporine A and FK506), supporting a regulatory role for $\mathrm{CN}$ in $\mathrm{Cx} 43$ dephosphorylation. Additionally, preliminary studies in our laboratory indicate that $\mathrm{CN}$ mediates the dephosphorylation of $\mathrm{Cx} 43$ ser368 in primary astrocytes exposed to IL-1 $\beta$ or the exogenous $\mathrm{Ca}^{2+}$ mobilizing agents ionomycin and phorbol ester [104]. Parallel investigations of Cx43 in postmortem human hippocampal tissue performed by our group further showed that Cx43 dephosphorylation (at ser368) is increased at early stages of cognitive decline and positively correlated with the levels of a proteolytically active form of $\mathrm{CN}$, suggesting that the $\mathrm{CN} / \mathrm{Cx} 43$ interaction may have relevance to the progression of neurodegeneration and/or dementia.

Despite these observations, the functional impact of the $\mathrm{CN} / \mathrm{Cx} 43$ interaction is not presently clear. Using a dyecoupling approach, $\mathrm{CN}$ inhibitors were initially shown to prevent the decoupling of GJs in astrocytes following a hypoxic insult [102]. Later studies similarly demonstrated a relationship between GJ inhibition and dephosphorylation of Cx43 ser368, but found that dephosphorylation does not necessarily cause GJ decoupling [103]. Instead, this report suggested that $\mathrm{Cx} 43$ dephosphorylation by $\mathrm{CN}$ occurs after GJ decoupling and leads to the redistribution of $\mathrm{Cx} 43$ to tight junctions. Clearly, additional studies are needed to clarify the role of $\mathrm{CN}$ in the regulation of gap junctions and determine whether this interaction significantly impacts astrocyte function in particular, and neurologic function in general (Figure 3).

\section{$\mathrm{CN}$ and astrocytic $\mathrm{Ca}^{2+}$ dysregulation}

Similar to neurons, activated astrocytes in models of aging, injury, and disease exhibit numerous signs of $\mathrm{Ca}^{2+}$ dysregulation including elevated expression of a variety of $\mathrm{Ca}^{2+}$ channels and $\mathrm{Ca}^{2+}$ regulated proteins, as well as higher intracellular $\mathrm{Ca}^{2+}$ levels and/or more frequent $\mathrm{Ca}^{2+}$ oscillations [105-107]. While it seems clear how these changes could help set the stage for hyperactive $\mathrm{CN}$ signaling, it is also important to note that $\mathrm{CN}$ may play an active role in promoting or disrupting $\mathrm{Ca}^{2+}$ homeostasis. At the transcriptional level, $\mathrm{CN}$ helps drive the expression of many key $\mathrm{Ca}^{2+}$ signaling mediators in multiple cell types [108-111]. At the post-translational level, $\mathrm{CN}$ directly or indirectly regulates plasma membrane $\mathrm{Ca}^{2+}$ channels, intracellular $\mathrm{Ca}^{2+}$ release channels, and $\mathrm{Ca}^{2+}$-dependent enzymes [2]. In astrocytes, inhibition of $\mathrm{CN}$ was recently shown to reduce $\mathrm{Ca}^{2+}$ transients evoked by $A \beta$ [21] and to suppress the upregulation of critical proteins involved in $\mathrm{Ca}^{2+}$-induced $\mathrm{Ca}^{2+}$ release, including IP3 receptor 1 and metabotropic glutamate receptor 5 [112]. Other potential targets for $\mathrm{CN}$ may be predicted from findings gleaned from neurons and other cell types. For instance, in neurons and cardiomyocytes, $\mathrm{CN}$ has been shown to enhance the function of L-type $\mathrm{Ca}^{2+}$ channels, which may, in turn, disrupt cellular activity and viability [113-116]. Though found at very low levels in astrocytes of healthy animals, L-type $\mathrm{Ca}^{2+}$ channels appear to be present at high levels in activated astrocytes following acute injury [117]. This differential pattern of expression in astrocytes is strikingly similar to that of $\mathrm{CN}$. Moreover, we have shown that $50 \%$ or more of CN/NFAT 
A

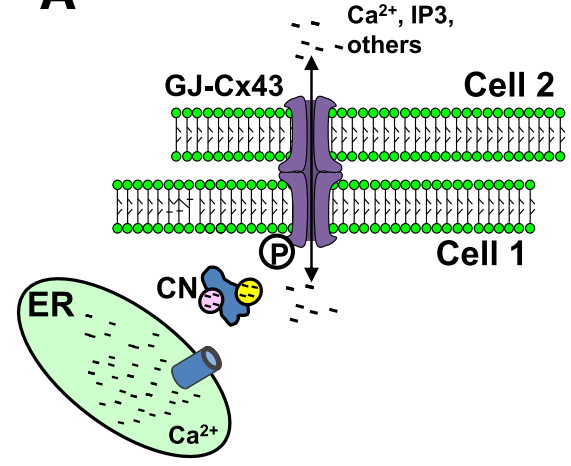

B

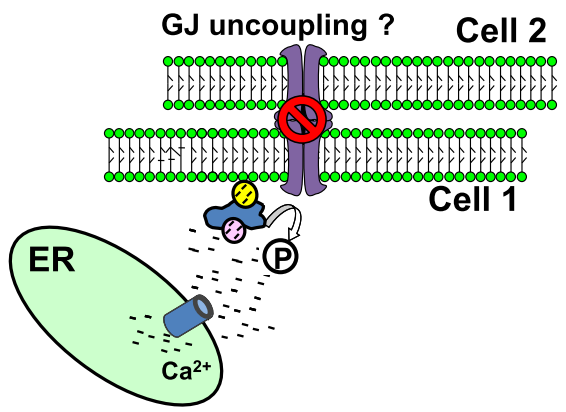

Figure 3 CN dephosphorylates Cx43 and modulates GJ coupling in astrocytes. (A) Cx hexamers on the astrocyte membrane form GJ channels with apposing Cx hexamers in adjacent cells and allow the intercellular passage of small molecules like $\mathrm{Ca}^{2+}$ and IP3. (B) Activation of astrocytes with inflammatory mediators stimulates $\mathrm{CN}$, which dephosphorylates the cytoplasmic tail of Cx43. Dephosphorylation of Cx43 is associated with reduced GJ coupling, though it is unclear whether dephosphorylation is a cause or consequence of decoupling.

activity in primary astrocytes treated with IL-1 $\beta$ is eliminated by co-treatment with the L-type $\mathrm{Ca}^{2+}$ channel blocker nifedipine [33], while others have shown that $\mathrm{CN}$ / NFAT signaling is stimulated in astrocytes treated with the L-type $\mathrm{Ca}^{2+}$ channel activator Bayk8644 [44]. These observations suggest that $\mathrm{CN} / \mathrm{L}$-type $\mathrm{Ca}^{2+}$ channel interactions may play a critical role in promoting $\mathrm{Ca}^{2+}$ dysregulation in activated astrocytes (Figure 4).

\section{$\mathrm{CN}$ and astrocyte-derived $\mathrm{A} \beta$ production}

In $\mathrm{AD}, \mathrm{CN}$ expression and activity levels are directly correlated to increasing levels of the $A \beta$ peptide [19]. $A \beta$ deposits in both human and mouse tissue are often surrounded by astrocytes that label very intensely for $\mathrm{CN}$
[18-20]. The sensitivity of $\mathrm{CN}$ activity to rising $A \beta$ levels has been well-documented by several different research groups using a variety of experimental models. Application of the pathogenic, oligomeric form of $A \beta$ rapidly and robustly activates $\mathrm{CN}$ signaling pathways in both neurons [71,118-123] and astrocytes [19,21,66,112] and leads to numerous deleterious neurologic changes including enhanced synaptic depression, impaired synaptic potentiation, glutamate dysregulation, dendritic atrophy, cell death, and cognitive deficits.

Interestingly, APP/PS1 mice treated with FK506 exhibit reductions in $\mathrm{A} \beta$ plaque load relative to vehicle-treated APP mice [124], suggesting that $\mathrm{CN}$ not only responds to elevated $A \beta$, but also actively contributes to the accumulation
A

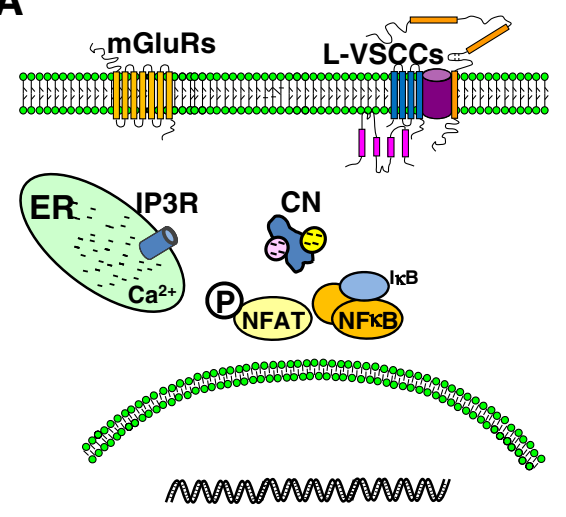

B

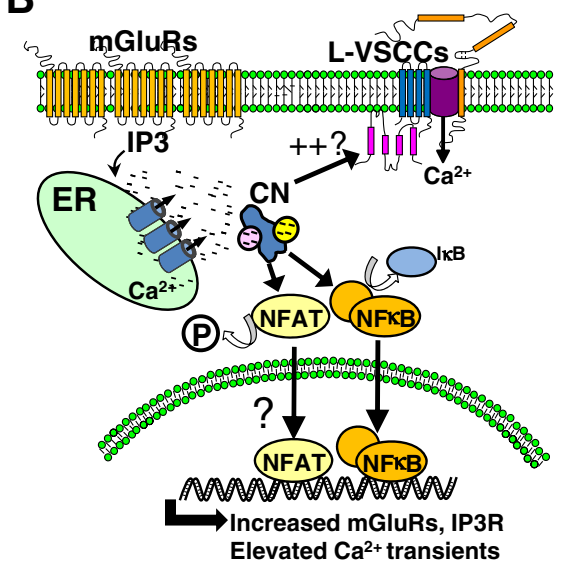

Figure $4 \mathbf{C N}$ is associated with $\mathrm{Ca}^{2+}$ dysregulation in astrocytes. (A) In healthy nervous tissue, elevations in intracellular $\mathrm{Ca}^{2+}$ are controlled, in part, by $\mathrm{Ca}^{2+}$ release channels (e.g., IP3Rs) located on the endoplasmic reticulum membrane. Levels of several different varieties of plasma membrane $\mathrm{Ca}^{2+}$ channels, including L-type $\mathrm{Ca}^{2+}$ channels are generally low in non-activated astrocytes. (B) Inflammatory mediators, like cytokines and $A B$, cause hyperactivation of CN and its target transcription factors, NFAT and NFKB. These events cause the transcriptional upregulation of IP3 receptors and mGluRs leading to increased $\mathrm{Ca}^{2+}$ transients and/or higher resting levels of cytosolic $\mathrm{Ca}^{2+}$. CN may also increase the function of L-type $\mathrm{Ca}^{2+}$ channels, which, like CN, are found at higher levels in activated astrocytes. 
of $A \beta$ pathology. Though the mechanisms through which $\mathrm{CN}$ modulates $\mathrm{A} \beta$ levels are unsettled, several studies indicate that the CN/NFAT signaling pathway positively regulates the expression of beta-secretases [66,125], the rate-limiting enzymes for formation of $A \beta$ peptides (Figure 5). Jin et al. [66] showed that the NFAT4 isoform binds to the beta-site APP cleaving enzyme 1 (BACE1) promoter in primary astrocytes, which in turn, helps drive $A \beta$ production in response to rising intracellular $\mathrm{Ca}^{2+}$ levels. Similarly, our group showed that inhibition of astrocytic NFAT activity reduces soluble A $\beta$ levels and plaque load in the hippocampus of APP/PS1 mice [43] in parallel with a reduction in BACE1 protein levels. We did not observe any changes in the levels for several key $A \beta$ clearing enzymes, including neprilysin and insulin degrading enzyme. Together, these findings are consistent with the notion that astrocytic NFAT/BACE1 interactions play an important role in amyloid regulation. Although BACE1 expression is very low in astrocytes of intact animals and humans, the sheer abundance of this cell type, relative to other cell types, could provide enough BACE activity to contribute significantly to the production of amyloid peptides and subsequent formation of parenchymal $A \beta$ deposits [126]. Nonetheless, effects of CN/NFAT on other key regulators of $\mathrm{A} \beta$ formation and clearance, including gamma secretases, apolipoprotein $\mathrm{E}$, and lipoprotein receptor-related protein 1 , among others, are not clear and will require further investigation.

In addition to directly influencing $A \beta$ production in astrocytes, it is perhaps just as likely that astrocytic $\mathrm{CN}$ indirectly influences $\mathrm{A} \beta$ production/metabolism in neurons. Indeed, numerous "pro-inflammatory" factors released by glial cells, many of which are sensitive to $\mathrm{CN}$ activity, have been shown to stimulate neuronal APP and/or A $\beta$ production, e.g., see [127-131]. Similarly, the loss of any number of protective glial properties during chronic activation/ neuroinflammation would be expected to disrupt $\mathrm{Ca}^{2+}$ homeostasis in neurons and/or erode neuronal viability leading to greater $A \beta$ levels [132-136]. Whether direct or indirect, these observations suggest that inhibition of astrocytic $\mathrm{CN}$ activity may be an effective strategy for slowing the progression of $A \beta$ pathology.

\section{Impact of astrocytic CN on neurologic function}

Numerous studies have shown that commercial $\mathrm{CN}$ inhibitors dampen glial activation, impart neuroprotection, and/or improve neurologic function in animal models of aging, injury, and disease [3,12]. Surely, at least some of these beneficial effects are attributable to direct inhibition of deleterious neuronal $\mathrm{CN}$ signaling pathways, which have been shown to play important roles in neuronal degeneration and altered synaptic function (e.g., see [105-107]). However, what about the impact of glial CN signaling? This is a difficult question to address in intact animals using basic pharmacologic reagents, given their lack of cellular specificity. To overcome this difficulty, our group recently employed an adeno-associated virusbased approach to selectively express the NFAT inhibitor, VIVIT, in hippocampal astrocytes of AD model mice [43]. Suppression of astrocytic NFAT signaling in presymptomatic mice was sufficient for reducing glial activation and $\mathrm{A} \beta$ plaque pathology during advanced age. Arguably more important, this knockdown also proved beneficial to neurologic function and plasticity, i.e., VIVITtreated mice showed improved synaptic strength, increased levels of long-term potentiation, and better avoidance learning relative to AD mice treated with vehicle or control adeno-associated virus vectors. These observations support a detrimental role for astrocytic CN/NFAT signaling in neurologic function and are consistent with cell culture

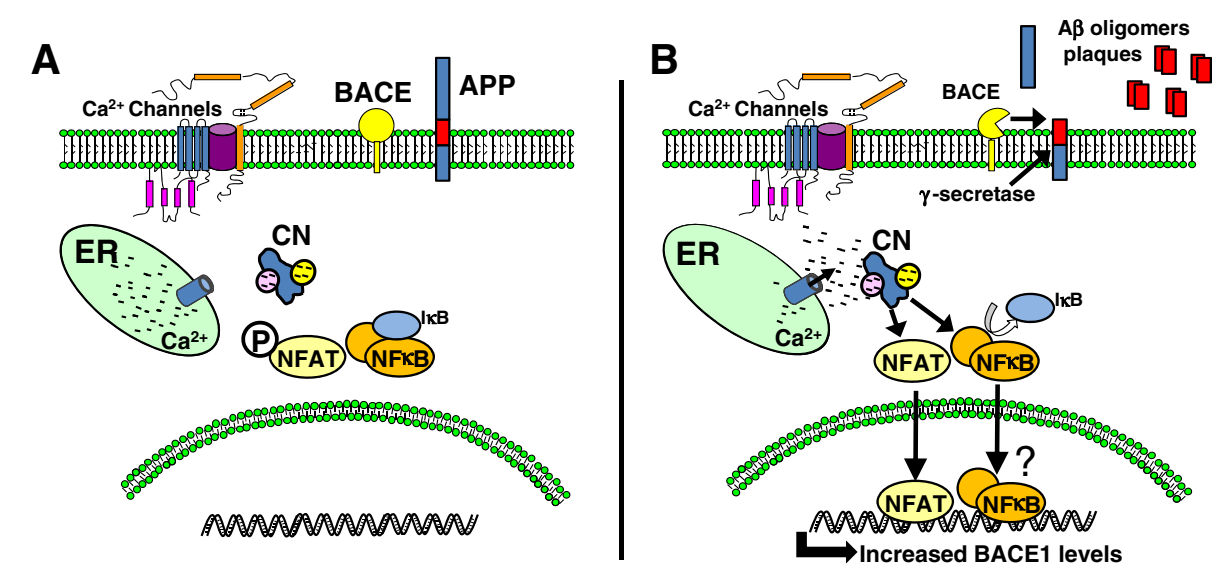

Figure $\mathbf{5}$ CN regulates $\mathbf{A} \boldsymbol{\beta}$ metabolism in astrocytes. (A) In resting astrocytes, BACE expression and activity levels are relatively low. (B) Activation of astrocytes with inflammatory mediators stimulates CN. Nuclear translocation of NFATs and possibly NFKB leads to the transcriptional upregulation of the protease BACE1 (the rate limiting enzyme for production of neurotoxic A $\beta$ peptides). Elevated levels of BACE1 are associated with the increased production of $A \beta$ peptides, which further aggregate and form $A \beta$ plaques. 
studies that report lower levels of pro-inflammatory cytokines, reduced $A \beta$ production/lower BACE1 activity, reduced $\mathrm{Ca}^{2+}$ transients, lower extracellular glutamate levels, reduced neuronal excitability, and less excitotoxic neuronal death following inhibition of astrocytic CN/NFATs as discussed in preceding sections.

In addition to directly suppressing NFAT activity, overexpression of VIVIT may help to divert $\mathrm{CN}$ activity to other substrates that are more protective in nature. For instance, Fernandez et al. [63] reported that overexpression of an activated form of $\mathrm{CN}$ in astrocytes of intact APP mice led to the increased association of $\mathrm{CN}$ with PPAR $\gamma$ and NFKB, which, in turn, reduced glial activation and amyloid pathology and improved cognition. Together with our findings, it is tempting to speculate that astrocytic $\mathrm{CN}$ is generally protective in astrocytes, unless it interacts extensively with NFAT transcription factors, in which case the astrocyte phenotype becomes harmful, marked by increased expression of pro-inflammatory cytokines, impaired glutamate uptake, and other deleterious properties.

\section{Conclusions}

We are just beginning to understand the contribution of $\mathrm{CN}$ to glial function. While it seems clear that $\mathrm{CN}$ is intimately involved in neuroinflammation, much work is still needed to fully assess the specific interactions between $\mathrm{CN}$-dependent and -independent transcription factors, and how these interactions regulate specific inflammatory phenotypes. While this review has focused primarily on the role of $\mathrm{CN}$ in astrocytes, other work showing similar roles of $\mathrm{CN}$ in microglia [56-58,74] underscores the necessity to characterize the signaling properties of $\mathrm{CN}$ in other glial subtypes. Furthermore, the identification of other cellular targets of $\mathrm{CN}$, including glutamate transporters, gap junctions, and BACE, suggests that CN's impact on glial function may extend well beyond immune/inflammatory signaling. These observations highlight some of the complexities facing future research into the role of glial $\mathrm{CN}$ signaling, but also hint at the potential of discovering new molecular targets for treating neural injury and neurodegenerative disease.

\footnotetext{
Abbreviations

Aß: $\beta$-amyloid; AD: Alzheimer's disease; AP1: Activator protein 1.

APP: Amyloid precursor protein; BACE1: Beta-site APP cleaving enzyme 1;

CaM: Calmodulin; CN: Calcineurin; CNS: Central nervous system;

Cx: Connexins; EAAT: Excitatory amino acid transporter; FOXO3: Forkhead

box O3; FOXP3: Forkhead box P3; GJ: Gap junction; GFAP: Glial fibrillary acidic protein; IGF-1: Insulin-like growth factor; IKB: Inhibitory k B; IL-1B: Interleukin 1 $\beta$; IP3: Inositol triphosphate; NFATs: Nuclear factor of activated T cells; NFKB: Nuclear factor k B; PPARy: Peroxisome proliferator-activated receptor; PS1: Presenilin 1; TNFa: Tumor necrosis factor a
}

\section{Competing interests}

The authors declare that they have no competing interests.

\section{Authors' contributions}

JLF and CMN researched and wrote this manuscript. Both authors read and approved the final manuscript.

\section{Acknowledgements}

Work supported by awards from the NIH (AG027297), the Kentucky Spinal Cord and Head Injury Research Trust (12-10A), and The Hazel Embry

Research Fund to CMN and an award from the PhRMA Foundation to JLF.

\section{Author details}

${ }^{1}$ Pharmacology and Nutritional Sciences and the Sanders-Brown Center on Aging, University of Kentucky College of Medicine, 800 South Limestone St., Lexington, KY 40536, USA. ²Department of Neurology, School of Medicine, Washington University, 660 South Euclid, St. Louis, MO 63110, USA.

Received: 26 July 2014 Accepted: 22 August 2014

Published online: 10 September 2014

\section{References}

1. Musson RE, Smit NP: Regulatory mechanisms of calcineurin phosphatase activity. Curr Med Chem 2011, 18:301-315

2. Baumgartel $K$, Mansuy IM: Neural functions of calcineurin in synaptic plasticity and memory. Learn Mem 2012, 19:375-384.

3. Norris CM: Calpain interactions with the protein phosphatase calcineurin in neurodegeneration. Adv Biochem Health Dis 2014, 8:17-45.

4. Stemmer PM, Klee CB: Dual calcium ion regulation of calcineurin by calmodulin and calcineurin B. Biochemistry 1994, 33:6859-6866.

5. Klee $C B$, Ren $H$, Wang $X$ : Regulation of the calmodulin-stimulated protein phosphatase, calcineurin. J Biol Chem 1998, 273:13367-13370.

6. Goto S, Matsukado Y, Mihara Y, Inoue N, Miyamoto E: The distribution of calcineurin in rat brain by light and electron microscopic immunohistochemistry and enzyme-immunoassay. Brain Res 1986, 397:161-172.

7. Goto S, Matsukado $Y$, Mihara $Y$, Inoue N, Miyamoto E: Calcineurin in human brain and its relation to extrapyramidal system. Immunohistochemical study on postmortem human brains. Acta Neuropathol 1986, 72:150-156.

8. Kuno T, Mukai H, Ito A, Chang CD, Kishima K, Saito N, Tanaka C: Distinct cellular expression of calcineurin $\mathrm{A}$ alpha and $\mathrm{A}$ beta in rat brain. J Neurochem 1992, 58:1643-1651.

9. Polli JW, Billingsley ML, Kincaid RL: Expression of the calmodulindependent protein phosphatase, calcineurin, in rat brain: developmental patterns and the role of nigrostriatal innervation. Brain Res Dev Brain Res 1991, 63:105-119.

10. Halpain S, Girault JA, Greengard P: Activation of NMDA receptors induces dephosphorylation of DARPP-32 in rat striatal slices. Nature 1990, 343:369-372.

11. Halpain S, Greengard P: Activation of NMDA receptors induces rapid dephosphorylation of the cytoskeletal protein MAP2. Neuron 1990, 5:237-246.

12. Reese LC, Taglialatela G: A role for calcineurin in Alzheimer's disease. Curr Neuropharmacol 2011, 9:685-692.

13. Abdul HM, Furman JL, Sama MA, Mathis DM, Norris CM: NFATs and Alzheimer's disease. Mol Cell Pharmacol 2010, 2:7-14

14. Vinade L, Goncalves CA, Wofchuk S, Gottfried C, Rodnight R: Evidence for a role for calcium ions in the dephosphorylation of glial fibrillary acidic protein (GFAP) in immature hippocampal slices and in astrocyte cultures from the rat. Brain Res Dev Brain Res 1997, 104:11-17.

15. Matsuda T, Takuma K, Asano S, Kishida Y, Nakamura H, Mori K, Maeda S, Baba A: Involvement of calcineurin in $\mathrm{Ca}^{2+}$ paradox-like injury of cultured rat astrocytes. J Neurochem 1998, 70:2004-2011.

16. Hashimoto T, Kawamata T, Saito N, Sasaki M, Nakai M, Niu S, Taniguchi T, Terashima A, Yasuda M, Maeda K, Tanaka C: Isoform-specific redistribution of calcineurin $A$ alpha and $A$ beta in the hippocampal CA1 region of gerbils after transient ischemia. J Neurochem 1998, 70:1289-1298.

17. Ferrari D, Stroh C, Schulze-Osthoff K: P2X7/P2Z purinoreceptor-mediated activation of transcription factor NFAT in microglial cells. J Biol Chem 1999, 274:13205-13210.

18. Norris CM, Kadish I, Blalock EM, Chen KC, Thibault V, Porter NM, Landfield PW, Kraner SD: Calcineurin triggers reactive/inflammatory processes in astrocytes and is upregulated in aging and Alzheimer's models. J Neurosci 2005, 25:4649-4658. 
19. Abdul HM, Sama MA, Furman JL, Mathis DM, Beckett TL, Weidner AM, Pate ES, Baig I, Murphy MP, LeVine H 3rd, Kraner SD, Norris CM: Cognitive decline in Alzheimer's disease is associated with selective changes in calcineurin/NFAT signaling. J Neurosci 2009, 29:12957-12969.

20. Celsi F, Svedberg M, Unger C, Cotman CW, Carri MT, Ottersen OP, Nordberg A, Torp R: Beta-amyloid causes downregulation of calcineurin in neurons through induction of oxidative stress. Neurobiol Dis 2007, 26:342-352.

21. Lim D, lyer A, Ronco V, Grolla AA, Canonico PL, Aronica E, Genazzani AA: Amyloid beta deregulates astroglial mGluR5-mediated calcium signaling via calcineurin and Nf-kB. Glia 2013, 61:1134-1145.

22. Verkhratsky A, Sofroniew MV, Messing A, deLanerolle NC, Rempe D, Rodriguez JJ, Nedergaard M: Neurological diseases as primary gliopathies: a reassessment of neurocentrism. ASN Neuro 2012, 4(3):e00082.

23. Schousboe A, Waagepetersen HS: Role of astrocytes in glutamate homeostasis: implications for excitotoxicity. Neurotox Res 2005, 8:221-225.

24. Maragakis NJ, Rothstein JD: Mechanisms of disease: astrocytes in neurodegenerative disease. Nat Clin Pract Neurol 2006, 2:679-689.

25. Eugenin EA, Basilio D, Saez JC, Orellana JA, Raine CS, Bukauskas F, Bennett MV, Berman JW: The role of gap junction channels during physiologic and pathologic conditions of the human central nervous system. J Neuroimmune Pharmacol 2012, 7:499-518.

26. Parpura V, Heneka MT, Montana V, Oliet SH, Schousboe A, Haydon PG, Stout RF Jr, Spray DC, Reichenbach A, Pannicke T, Pekny M, Pekna M, Zorec R, Verkhratsky A: Glial cells in (patho)physiology. J Neurochem 2012, 121:4-27.

27. Sofroniew MV, Vinters HV: Astrocytes: biology and pathology. Acta Neuropathol 2010, 119:7-35.

28. Pekny M, Nilsson M: Astrocyte activation and reactive gliosis. Glia 2005 , 50:427-434

29. Sofroniew MV: Molecular dissection of reactive astrogliosis and glial scar formation. Trends Neurosci 2009, 32:638-647.

30. Pekny $M$, Wilhelmsson U, Pekna M: The dual role of astrocyte activation and reactive gliosis. Neurosci Lett 2014, 565:30-38.

31. Akama KT, Albanese C, Pestell RG, Van Eldik LJ: Amyloid beta-peptide stimulates nitric oxide production in astrocytes through an NFkappaBdependent mechanism. Proc Natl Acad Sci U S A 1998, 95:5795-5800.

32. Keene SD, Greco TM, Parastatidis I, Lee SH, Hughes EG, Balice-Gordon RJ, Speicher DW, Ischiropoulos H: Mass spectrometric and computational analysis of cytokine-induced alterations in the astrocyte secretome. Proteomics 2009, 9:768-782.

33. Sama MA, Mathis DM, Furman JL, Abdul HM, Artiushin IA, Kraner SD, Norris CM: Interleukin-1 beta-dependent signaling between astrocytes and neurons depends critically on astrocytic calcineurin/NFAT activity. J Biol Chem 2008, 283:21953-21964.

34. Fuller S, Steele M, Munch G: Activated astroglia during chronic inflammation in Alzheimer's disease-do they neglect their neurosupportive roles? Mutat Res 2010, 690:40-49.

35. Carter SF, Scholl M, Almkvist O, Wall A, Engler H, Langstrom B, Nordberg A: Evidence for astrocytosis in prodromal Alzheimer disease provided by 11C-deuterium-L-deprenyl: a multitracer PET paradigm combining 11C-Pittsburgh compound B and 18F-FDG. J Nucl Med 2012, 53:37-46.

36. Owen JB, Di Domenico F, Sultana R, Perluigi M, Cini C, Pierce WM, Butterfield DA: Proteomics-determined differences in the concanavalin-Afractionated proteome of hippocampus and inferior parietal lobule in subjects with Alzheimer's disease and mild cognitive impairment: implications for progression of AD. J Proteome Res 2009, 8:471-482.

37. Schipper HM, Bennett DA, Liberman A, Bienias JL, Schneider JA, Kelly J, Arvanitakis Z: Glial heme oxygenase-1 expression in Alzheimer disease and mild cognitive impairment. Neurobiol Aging 2006, 27:252-261.

38. Crabtree GR, Olson EN: NFAT signaling: choreographing the social lives of cells. Cell 2002, 109(Suppl):S67-S79.

39. Horsley $\mathrm{V}$, Pavlath GK: NFAT: ubiquitous regulator of cell differentiation and adaptation. J Cell Biol 2002, 156:771-774.

40. Rao A, Luo C, Hogan PG: Transcription factors of the NFAT family: regulation and function. Annu Rev Immunol 1997, 15:707-747.

41. Liou HC, Baltimore D: Regulation of the NF-kappa B/rel transcription factor and I kappa B inhibitor system. Curr Opin Cell Biol 1993, 5:477-487.

42. Palkowitsch L, Marienfeld U, Brunner C, Eitelhuber A, Krappmann D, Marienfeld RB: The Ca2 +-dependent phosphatase calcineurin controls the formation of the Carma1-Bcl10-Malt1 complex during T cell receptor-induced NF-kappaB activation. J Biol Chem 2011, 286:7522-7534.
43. Furman JL, Sama DM, Gant JC, Beckett TL, Murphy MP, Bachstetter AD, Van Eldik LJ, Norris CM: Targeting astrocytes ameliorates neurologic changes in a mouse model of Alzheimer's disease. J Neurosci 2012, 32:16129-16140.

44. Canellada A, Ramirez BG, Minami T, Redondo JM, Cano E: Calcium/ calcineurin signaling in primary cortical astrocyte cultures: Rcan1-4 and cyclooxygenase-2 as NFAT target genes. Glia 2008, 56:709-722.

45. Fernandez AM, Fernandez S, Carrero P, Garcia-Garcia M, Torres-Aleman I: Calcineurin in reactive astrocytes plays a key role in the interplay between proinflammatory and anti-inflammatory signals. J Neurosci 2007, 27:8745-8756

46. Leal RB, Frizzo JK, Tramontina F, Fieuw-Makaroff S, Bobrovskaya L, Dunkley PR, Goncalves CA: S100B protein stimulates calcineurin activity. Neuroreport 2004, 15:317-320.

47. Perez-Ortiz JM, Serrano-Perez MC, Pastor MD, Martin ED, Calvo S, Rincon M Tranque P: Mechanical lesion activates newly identified NFATc1 in primary astrocytes: implication of ATP and purinergic receptors. Eur J Neurosci 2008, 27:2453-2465.

48. Furman $\mathrm{J}$, Artiushin IA, Norris CM: Disparate effects of serum on basal and evoked NFAT activity in primary astrocyte cultures. Neurosci Lett 2010, 469:365-369.

49. Blalock EM, Chen KC, Sharrow K, Herman JP, Porter NM, Foster TC, Landfield PW: Gene microarrays in hippocampal aging: statistical profiling identifies novel processes correlated with cognitive impairment. J Neurosci 2003, 23:3807-3819.

50. Blalock EM, Geddes JW, Chen KC, Porter NM, Markesbery WR, Landfield PW: Incipient Alzheimer's disease: microarray correlation analyses reveal major transcriptional and tumor suppressor responses. Proc Natl Acad Sci U S A 2004, 101:2173-2178

51. Kadish I, Thibault O, Blalock EM, Chen KC, Gant JC, Porter NM, Landfield PW: Hippocampal and cognitive aging across the lifespan: a bioenergetic shift precedes and increased cholesterol trafficking parallels memory impairment. J Neurosci 2009, 29:1805-1816.

52. Wilcock DM: Neuroinflammatory phenotypes and their roles in Alzheimer's disease. Neurodegener Dis 2014, 13:183-185.

53. Mrak RE, Griffin WS: The role of activated astrocytes and of the neurotrophic cytokine S100B in the pathogenesis of Alzheimer's disease. Neurobiol Aging 2001, 22:915-922

54. Mrak RE, Griffin WS: Glia and their cytokines in progression of neurodegeneration. Neurobiol Aging 2005, 26:349-354

55. Griffin WS, Sheng JG, Royston MC, Gentleman SM, McKenzie JE, Graham DI, Roberts GW, Mrak RE: Glial-neuronal interactions in Alzheimer's disease: the potential role of a 'cytokine cycle' in disease progression. Brain Pathol 1998, 8:65-72.

56. Nagamoto-Combs K, Combs CK: Microglial phenotype is regulated by activity of the transcription factor, NFAT (nuclear factor of activated T cells). J Neurosci 2010, 30:9641-9646.

57. Kataoka A, Tozaki-Saitoh H, Koga Y, Tsuda M, Inoue K: Activation of P2X7 receptors induces CCL3 production in microglial cells through transcription factor NFAT. J Neurochem 2009, 108:115-125.

58. Shiratori M, Tozaki-Saitoh H, Yoshitake M, Tsuda M, Inoue K: P2X7 receptor activation induces CXCL2 production in microglia through NFAT and PKC/MAPK pathways. J Neurochem 2010, 114:810-819.

59. Kim B, Jeong HK, Kim JH, Lee SY, Jou I, Joe EH: Uridine 5'-diphosphate induces chemokine expression in microglia and astrocytes through activation of the P2Y6 receptor. J Immunol 2011, 186:3701-3709.

60. Im SH, Rao A: Activation and deactivation of gene expression by $\mathrm{Ca}^{2}$ ${ }^{+}$/calcineurin-NFAT-mediated signaling. Mol Cells 2004, 18:1-9.

61. Rudensky AY, Gavin M, Zheng Y: FOXP3 and NFAT: partners in tolerance. Cell 2006, 126:253-256.

62. Wu Y, Borde M, Heissmeyer V, Feuerer M, Lapan AD, Stroud JC, Bates DL, Guo L, Han A, Ziegler SF, Mathis D, Benoist C, Chen L, Rao A: FOXP3 controls regulatory $T$ cell function through cooperation with NFAT. Cell 2006, 126:375-387.

63. Fernandez AM, Jimenez S, Mecha M, Davila D, Guaza C, Vitorica J, Torres-Aleman I: Regulation of the phosphatase calcineurin by insulin-like growth factor I unveils a key role of astrocytes in Alzheimer's pathology. Mol Psychiatry 2012, 17:705-718.

64. Abbott KL, Friday BB, Thaloor D, Murphy TJ, Pavlath GK: Activation and cellular localization of the cyclosporine A-sensitive transcription factor NF-AT in skeletal muscle cells. Mol Biol Cell 1998, 9:2905-2916. 
65. Calabria E, Ciciliot S, Moretti I, Garcia M, Picard A, Dyar KA, Pallafacchina G, Tothova J, Schiaffino S, Murgia M: NFAT isoforms control activity-dependent muscle fiber type specification. Proc Natl Acad Sci U S A 2009, 106:13335-13340.

66. Jin SM, Cho HJ, Kim YW, Hwang JY, Mook-Jung I: Abeta-induced $\mathrm{Ca}(2+)$ influx regulates astrocytic BACE1 expression via calcineurin/NFAT4 signals. Biochem Biophys Res Commun 2012, 425:649-655.

67. Serrano-Perez MC, Martin ED, Vaquero CF, Azcoitia I, Calvo S, Cano E Tranque P: Response of transcription factor NFATc3 to excitotoxic and traumatic brain insults: identification of a subpopulation of reactive astrocytes. Glia 2011, 59:94-107.

68. Yan HQ, Shin SS, Ma X, Li Y, Dixon CE: Differential effect of traumatic brain injury on the nuclear factor of activated T Cells C3 and C4 isoforms in the rat hippocampus. Brain Res 2014, 1548:63-72.

69. Luoma Jl, Zirpel L: Deafferentation-induced activation of NFAT (nuclear factor of activated T-cells) in cochlear nucleus neurons during a developmental critical period: a role for NFATc4-dependent apoptosis in the CNS. J Neurosci 2008, 28:3159-3169.

70. Shioda N, Han F, Moriguchi S, Fukunaga K: Constitutively active calcineurin mediates delayed neuronal death through Fas-ligand expression via activation of NFAT and FKHR transcriptional activities in mouse brain ischemia. J Neurochem 2007, 102:1506-1517.

71. Hudry E, Wu HY, Arbel-Ornath M, Hashimoto T, Matsouaka R, Fan Z, Spires-Jones TL, Betensky RA, Bacskai BJ, Hyman BT: Inhibition of the NFAT pathway alleviates amyloid beta neurotoxicity in a mouse model of Alzheimer's disease. J Neurosci 2012, 32:3176-3192.

72. Yamaguchi R, Hosaka M, Torii S, Hou N, Saito N, Yoshimoto Y, Imai H, Takeuchi T: Cyclophilin C-associated protein regulation of phagocytic functions via NFAT activation in macrophages. Brain Res 2011, 1397:55-65.

73. Neria F, del Carmen S-PM, Velasco P, Urso K, Tranque P, Cano E: NFATc3 promotes $\mathrm{Ca}(2+)$-dependent MMP3 expression in astroglial cells. Glia 2013, 61:1052-1066.

74. Rojanathammanee L, Puig KL, Combs CK: Pomegranate polyphenols and extract inhibit nuclear factor of activated T-cell activity and microglial activation in vitro and in a transgenic mouse model of Alzheimer disease. J Nutr 2013, 143:597-605.

75. Maragakis NJ, Rothstein JD: Glutamate transporters: animal models to neurologic disease. Neurobiol Dis 2004, 15:461-473.

76. Sultana R, Butterfield DA: Alterations of some membrane transport proteins in Alzheimer's disease: role of amyloid beta-peptide. Mol Biosyst 2008, 4:36-41.

77. Scimemi A, Meabon JS, Woltjer RL, Sullivan JM, Diamond JS, Cook DG: Amyloid-beta1-42 slows clearance of synaptically released glutamate by mislocalizing astrocytic GLT-1. J Neurosci 2013, 33:5312-5318.

78. Matos M, Augusto E, Machado NJ, dos Santos-Rodrigues A, Cunha RA, Agostinho P: Astrocytic adenosine A2A receptors control the amyloid-beta peptide-induced decrease of glutamate uptake. J Alzheimers Dis 2012, 31:555-567.

79. Schallier A, Smolders I, Van Dam D, Loyens E, De Deyn PP, Michotte A, Michotte $Y$, Massie A: Region- and age-specific changes in glutamate transport in the AbetaPP23 mouse model for Alzheimer's disease. J Alzheimers Dis 2011, 24:287-300.

80. Tian G, Kong Q, Lai L, Ray-Chaudhury A, Lin CL: Increased expression of cholesterol 24S-hydroxylase results in disruption of glial glutamate transporter EAAT2 association with lipid rafts: a potential role in Alzheimer's disease. J Neurochem 2010, 113:978-989.

81. Matos M, Augusto E, Oliveira CR, Agostinho P: Amyloid-beta peptide decreases glutamate uptake in cultured astrocytes: involvement of oxidative stress and mitogen-activated protein kinase cascades. Neuroscience 2008, 156:898-910.

82. Jacob CP, Koutsilieri E, Bartl J, Neuen-Jacob E, Arzberger T, Zander N, Ravid $R$, Roggendorf W, Riederer P, Grunblatt E: Alterations in expression of glutamatergic transporters and receptors in sporadic Alzheimer's disease. J Alzheimers Dis 2007, 11:97-116.

83. Lauderback CM, Hackett JM, Huang FF, Keller JN, Szweda LI, Markesbery WR, Butterfield DA: The glial glutamate transporter, GLT-1, is oxidatively modified by 4-hydroxy-2-nonenal in the Alzheimer's disease brain: the role of Abeta1-42. J Neurochem 2001, 78:413-416.

84. Katagiri H, Tanaka K, Manabe T: Requirement of appropriate glutamate concentrations in the synaptic cleft for hippocampal LTP induction. Eur J Neurosci 2001, 14:547-553.
85. Rothstein JD, Dykes-Hoberg M, Pardo CA, Bristol LA, Jin L, Kund RW, Kanai Y, Hediger MA, Wang Y, Schielke JP, Welty DF: Knockout of glutamate transporters reveals a major role for astroglial transport in excitotoxicity and clearance of glutamate. Neuron 1996, 16:675-686.

86. Mookherjee P, Green PS, Watson GS, Marques MA, Tanaka K, Meeker KD, Meabon JS, Li N, Zhu P, Olson VG, Cook DG: GLT-1 loss accelerates cognitive deficit onset in an Alzheimer's disease animal model. J Alzheimers Dis 2011, 26:447-455.

87. Simpson JE, Ince PG, Lace G, Forster G, Shaw PJ, Matthews F, Savva G, Brayne C, Wharton SB: Astrocyte phenotype in relation to Alzheimer-type pathology in the ageing brain. Neurobiol Aging 2010, 31(4):578-590.

88. Fang J, Han D, Hong J, Tan Q, Tian Y: The chemokine, macrophage inflammatory protein-2gamma, reduces the expression of glutamate transporter- 1 on astrocytes and increases neuronal sensitivity to glutamate excitotoxicity. J Neuroinflammation 2012, 9:267.

89. Boycott HE, Wilkinson JA, Boyle JP, Pearson HA, Peers C: Differential involvement of TNF alpha in hypoxic suppression of astrocyte glutamate transporters. Glia 2008, 56:998-1004.

90. Fine SM, Angel RA, Perry SW, Epstein LG, Rothstein JD, Dewhurst S, Gelbard HA: Tumor necrosis factor alpha inhibits glutamate uptake by primary human astrocytes. Implications for pathogenesis of HIV-1 dementia. J Biol Chem 1996, 271:15303-15306.

91. Tilleux S, Hermans E: Neuroinflammation and regulation of glial glutamate uptake in neurological disorders. J Neurosci Res 2007, 85:2059-2070.

92. Su ZZ, Leszczyniecka M, Kang DC, Sarkar D, Chao W, Volsky DJ, Fisher PB: Insights into glutamate transport regulation in human astrocytes: cloning of the promoter for excitatory amino acid transporter 2 (EAAT2). Proc Natl Acad Sci U S A 2003, 100:1955-1960.

93. De Bock M, Decrock E, Wang N, Bol M, Vinken M, Bultynck G, Leybaert L: The dual face of connexin-based astroglial $\mathrm{Ca}^{2+}$ communication: a key player in brain physiology and a prime target in pathology. Biochim Biophys Acta 2014, 1843(10):2211-2232.

94. Kielian T: Glial connexins and gap junctions in CNS inflammation and disease. J Neurochem 2008, 106:1000-1016.

95. Lutz SE, Zhao Y, Gulinello M, Lee SC, Raine CS, Brosnan CF: Deletion of astrocyte connexins 43 and 30 leads to a dysmyelinating phenotype and hippocampal CA1 vacuolation. J Neurosci 2009, 29:7743-7752.

96. Wallraff A, Kohling R, Heinemann U, Theis M, Willecke K, Steinhauser C: The impact of astrocytic gap junctional coupling on potassium buffering in the hippocampus. J Neurosci 2006, 26:5438-5447.

97. Theis M, Jauch R, Zhuo L, Speidel D, Wallraff A, Doring B, Frisch C, Sohl G, Teubner B, Euwens C, Huston J, Steinhäuser C, Messing A, Heinemann U, Willecke K: Accelerated hippocampal spreading depression and enhanced locomotory activity in mice with astrocyte-directed inactivation of connexin43. J Neurosci 2003, 23:766-776.

98. Lin JH, Weigel H, Cotrina ML, Liu S, Bueno E, Hansen AJ, Hansen TW, Goldman S, Nedergaard M: Gap-junction-mediated propagation and amplification of cell injury. Nat Neurosci 1998, 1:494-500.

99. Kielian T, Esen N: Effects of neuroinflammation on glia-glia gap junctional intercellular communication: a perspective. Neurochem Int 2004, 45:429-436.

100. Orellana JA, Martinez AD, Retamal MA: Gap junction channels and hemichannels in the CNS: regulation by signaling molecules. Neuropharmacology 2013, 75:567-582.

101. Lampe PD, Lau AF: The effects of connexin phosphorylation on gap junctional communication. Int J Biochem Cell Biol 2004, 36:1171-1186.

102. Li WE, Nagy J: Connexin43 phosphorylation state and intercellular communication in cultured astrocytes following hypoxia and protein phosphatase inhibition. Eur J Neurosci 2000, 12:2644-2650.

103. Tence M, Ezan P, Amigou E, Giaume C: Increased interaction of connexin43 with zonula occludens- 1 during inhibition of gap junctions by $\mathrm{G}$ protein-coupled receptor agonists. Cell Signal 2012, 24:86-98.

104. Furman JL, Mohmmad Abdul H, Norris CM: Alterations in connexin 43 phosphorylation during the progression of Alzheimer's disease: possible role of astrocytic calcineurin. Alzheimers Dement 2012, 8:P300.

105. Kuchibhotla KV, Lattarulo CR, Hyman BT, Bacskai BJ: Synchronous hyperactivity and intercellular calcium waves in astrocytes in Alzheimer mice. Science 2009, 323:1211-1215.

106. Lin DT, Wu J, Holstein D, Upadhyay G, Rourk W, Muller E, Lechleiter JD: $\mathrm{Ca}^{2+}$ signaling, mitochondria and sensitivity to oxidative stress in aging astrocytes. Neurobiol Aging 2007, 28:99-111. 
107. Sama DM, Norris CM: Calcium dysregulation and neuroinflammation: discrete and integrated mechanisms for age-related synaptic dysfunction. Ageing Res Rev 2013, 12:982-995.

108. Carafoli E, Genazzani A, Geurini D: Calcium controls the transcription of its own transporters and channels in developing neurons. Biochem Biophys Res Comm 1999, 266:624-632.

109. Genazzani AA, Carafoli E, Guerini D: Calcineurin controls inositol 1,4,5trisphosphate type 1 receptor expression in neurons. Proc Natl Acad Sci U S A 1999, 96:5797-5801.

110. Graef IA, Mermelstein PG, Stankunas K, Neilson JR, Deisseroth K, Tsien RW, Crabtree GR: L-type calcium channels and GSK-3 regulate the activity of NF-ATc4 in hippocampal neurons. Nature 1999, 401:703-708.

111. Groth RD, Coicou LG, Mermelstein PG, Seybold VS: Neurotrophin activation of NFAT-dependent transcription contributes to the regulation of pro-nociceptive genes. I Neurochem 2007, 102:1162-1174

112. Grolla AA, Fakhfouri G, Balzaretti G, Marcello E, Gardoni F, Canonico PL, DiLuca M, Genazzani AA, Lim D: A $\beta$ leads to $\mathrm{Ca}^{2+}$ signaling alterations and transcriptional changes in glial cells. Neurobiol Aging 2013, 34:511-522.

113. Norris CM, Blalock EM, Chen KC, Porter NM, Landfield PW: Calcineurin enhances L-type $\mathrm{Ca}^{2+}$ channel activity in hippocampal neurons: increased effect with age in culture. Neuroscience 2002, 110:213-225.

114. Norris CM, Blalock EM, Chen KC, Porter NM, Thibault O, Kraner SD, Landfield PW: Hippocampal 'zipper' slice studies reveal a necessary role for calcineurin in the increased activity of L-type $\mathrm{Ca}^{2+}$ channels with aging Neurobiol Aging 2010, 31:328-338.

115. Yatani A, Honda R, Tymitz KM, Lalli MJ, Molkentin JD: Enhanced Ca ${ }^{2+}$ channel currents in cardiac hypertrophy induced by activation of calcineurin-dependent pathway. J Mol Cell Cardiol 2001, 33:249-259.

116. Tandan S, Wang Y, Wang TT, Jiang N, Hall DD, Hell JW, Luo X, Rothermel BA, Hill JA: Physical and functional interaction between calcineurin and the cardiac L-type $\mathrm{Ca}^{2+}$ channel. Circ Res 2009, 105:51-60.

117. Westenbroek RE, Bausch SB, Lin RC, Franck JE, Noebels JL, Catterall WA: Upregulation of $\mathrm{L}$-type $\mathrm{Ca}^{2+}$ channels in reactive astrocytes after brain injury, hypomyelination, and ischemia. J Neurosci 1998, 18:2321-2334.

118. Shankar GM, Bloodgood BL, Townsend M, Walsh DM, Selkoe DJ, Sabatini BL: Natural oligomers of the Alzheimer amyloid-beta protein induce reversible synapse loss by modulating an NMDA-type glutamate receptor-dependent signaling pathway. J Neurosci 2007, 27:2866-2875.

119. Wu HY, Hudry E, Hashimoto T, Kuchibhotla K, Rozkalne A, Fan Z, SpiresJones T, Xie H, Arbel-Ornath M, Grosskreutz CL, Bacskai BJ, Hyman BT: Amyloid beta induces the morphological neurodegenerative triad of spine loss, dendritic simplification, and neuritic dystrophies through calcineurin activation. J Neurosci 2010, 30:2636-2649.

120. Reese LC, Zhang W, Dineley KT, Kayed R, Taglialatela G: Selective induction of calcineurin activity and signaling by oligomeric amyloid beta. Aging Cell 2008, 7:824-835.

121. Zhao WQ, Santini F, Breese R, Ross D, Zhang XD, Stone DJ, Ferrer M Townsend M, Wolfe AL, Seager MA, Kinney GG, Shughrue PJ, Ray WJ: Inhibition of calcineurin-mediated endocytosis and alpha-amino-3 hydroxy-5-methyl-4-isoxazolepropionic acid (AMPA) receptors prevents amyloid beta oligomer-induced synaptic disruption. J Biol Chem 2010, 285:7619-7632.

122. Kuchibhotla KV, Goldman ST, Lattarulo CR, Wu HY, Hyman BT, Bacskai BJ: Abeta plaques lead to aberrant regulation of calcium homeostasis in vivo resulting in structural and functional disruption of neuronal networks. Neuron 2008, 59:214-225.

123. Agostinho P, Lopes JP, Velez Z, Oliveira CR: Overactivation of calcineurin induced by amyloid-beta and prion proteins. Neurochem Int 2008, 52:1226-1233.

124. Hong HS, Hwang JY, Son SM, Kim YH, Moon M, Inhee MJ: FK506 reduces amyloid plaque burden and induces MMP-9 in AbetaPP/PS1 double transgenic mice. J Alzheimers Dis 2010, 22:97-105.

125. Cho HJ, Jin SM, Youn HD, Huh K, Mook-Jung I: Disrupted intracellular calcium regulates BACE1 gene expression via nuclear factor of activated T cells 1 (NFAT 1) signaling. Aging Cell 2008, 7:137-147.

126. Zhao J, O'Connor T, Vassar R: The contribution of activated astrocytes to Abeta production: implications for Alzheimer's disease pathogenesis. J Neuroinflammation 2011, 8:150.

127. Forloni G, Demicheli F, Giorgi S, Bendotti C, Angeretti N: Expression of amyloid precursor protein mRNAs in endothelial, neuronal and glial cells: modulation by interleukin-1. Brain Res Mol Brain Res 1992, 16:128-134
128. Li Y, Wang J, Sheng JG, Liu L, Barger SW, Jones RA, Van Eldik LJ, Mrak RE, Griffin WS: S100 beta increases levels of beta-amyloid precursor protein and its encoding mRNA in rat neuronal cultures. J Neurochem 1998, 71:1421-1428.

129. Sastre MI Dewachter I, Landreth GE, Willson TM, Klockgether T, van Leuven F, Heneka MT: Nonsteroidal anti-inflammatory drugs and peroxisome proliferator-activated receptor-gamma agonists modulate immunostimulated processing of amyloid precursor protein through regulation of beta-secretase. J Neurosci 2003, 23:9796-9804.

130. Yamamoto M, Kiyota T, Horiba M, Buescher JL, Walsh SM, Gendelman HE, Ikezu T: Interferon-gamma and tumor necrosis factor-alpha regulate amyloid-beta plaque deposition and beta-secretase expression in Swedish mutant APP transgenic mice. Am J Pathol 2007, 170:680-692.

131. Sutinen EM, Pirttilä T, Anderson G, Salminen A, Ojala JO: Pro-inflammatory interleukin-18 increases Alzheimer's disease-associated amyloid- $\beta$ production in human neuron-like cells. J Neuroinflammation 2012, 9:199.

132. Chen XH, Siman R, Iwata A, Meaney DF, Trojanowski JQ, Smith DH: Longterm accumulation of amyloid-beta, beta-secretase, presenilin-1, and caspase- 3 in damaged axons following brain trauma. Am J Pathol 2004, 165:357-371.

133. Pierrot N, Ghisdal P, Caumont AS, Octave JN: Intraneuronal amyloid-beta1-42 production triggered by sustained increase of cytosolic calcium concentration induces neuronal death. J Neurochem 2004, 88:1140-1150.

134. Chen XH, Johnson VE, Uryu K, Trojanowski JQ, Smith DH: A lack of amyloid beta plaques despite persistent accumulation of amyloid beta in axons of long-term survivors of traumatic brain injury. Brain Pathol 2009, 19:214-223.

135. Alley GM, Bailey JA, Chen D, Ray B, Puli LK, Tanila H, Banerjee PK, Lahiri DK. Memantine lowers amyloid-beta peptide levels in neuronal cultures and in APP/PS1 transgenic mice. J Neurosci Res 2010, 88:143-154.

136. Marklund N, Farrokhnia N, Hånell A, Vanmechelen E, Enblad P, Zetterberg $H$, Blennow K, Hillered L: Monitoring of $\beta$-amyloid dynamics after human traumatic brain injury. J Neurotrauma 2014, 31:42-55.

doi:10.1186/s12974-014-0158-7

Cite this article as: Furman and Norris: Calcineurin and glial signaling: neuroinflammation and beyond. Journal of Neuroinflammation 2014 11:158.

\section{Submit your next manuscript to BioMed Central and take full advantage of:}

- Convenient online submission

- Thorough peer review

- No space constraints or color figure charges

- Immediate publication on acceptance

- Inclusion in PubMed, CAS, Scopus and Google Scholar

- Research which is freely available for redistribution 